\title{
Hearing Loss and Associated Factors Among Noise-Exposed Workers in Palm Oil Mills
}

\author{
Daniel Raj Rasasoran' \\ Azman Atil (D) ${ }^{2}$ \\ Mohammad Saffree Jeffree (iD ${ }^{2}$ \\ Sahipudin Saupin (iD) ${ }^{2}$ \\ Khamisah Awang Lukman iD ${ }^{3}$ \\ 'Department of Occupational Safety and \\ Health, Kota Kinabalu, Sabah, Malaysia; \\ ${ }^{2}$ Occupational and Environmental Health \\ Unit, Community and Family Medicine \\ Department, Faculty of Medicine and \\ Health Sciences, Universiti Malaysia \\ Sabah, Kota Kinabalu, Malaysia; ${ }^{3}$ Centre \\ for Occupational Safety and Health, \\ Universiti Malaysia Sabah, Kota Kinabalu, \\ Malaysia
}

Correspondence: Mohammad Saffree Jeffree

Occupational and Environmental Health Unit, Community and Family Medicine Department, Faculty of Medicine and Health Sciences, Universiti Malaysia Sabah, Jalan UMS, Kota Kinabalu, 88400, Sabah, Malaysia

Tel +6088-320000 (ext 6I I00I)

Fax +6088-321377

Email saffree@ums.edu.my
Introduction: Almost $90 \%$ of the reported occupational diseases in Sabah, Malaysian Borneo were due to hearing loss. The manufacturing industry was the main contributor to this problem. This study aims to identify the prevalence and associated factors for hearing loss among workers in the palm oil manufacturing industry in Sabah.

Material and Methods: A cross-sectional study was done among 312 respondents from five palm oil mills in Sabah from January to April 2019. Audiometric tests, validated questionnaires and sound level meters were used. Chi-square test and independent $t$-test were conducted to determine the associated factors for hearing loss.

Results: $75 \%(\mathrm{n}=234)$ of the respondents were diagnosed with hearing loss. Most of them were male $(96.2 \%)$ with a mean age of 44.4 (SD 9.8) years, mean duration of employment of 16.2 (SD 9.7) years and mean noise exposure of 96.1 (SD 4.8) $\mathrm{dB}(\mathrm{A})$. The significant factors associated with hearing loss were older age $(p=0.001)$, married $(p=0.001)$, blue-collar jobs $(\mathrm{p}=0.003)$, smoking $(\mathrm{p}=0.001)$, works with noisy machinery $(\mathrm{p}=0.005)$, lower level of noise exposed $(p=0.015)$, longer duration of employment $(p=0.001)$, and longer overtime hours per week $(\mathrm{p}=0.001)$.

Conclusion: The prevalence of hearing loss among workers in the noise-exposed palm oil industries was high. Annual audiometry testing and job rotation from noise-exposed workstations were recommended. A smoking cessation program may help but reduction of noise from the source by engineering control is still the best method.

Keywords: hearing loss, palm oil mill, noise exposed workers

\section{Introduction}

Workers are exposed to noise in any working environment, but it can be harmful when it is too loud and long-lasting. Continuous exposure may damage the sensitive structures in the inner ear and cause noise-induced hearing loss (NIHL). A study done in the United States of America (USA) estimated that nearly 40 million adults developed hearing loss from exposure to loud noise. ${ }^{1}$ The World Health Organization (WHO) has previously noted that noise exposure appears to be increasing despite the other environmental health problems, which have diminished over time through regulation. ${ }^{2}$ NIHL is one of the most common occupational injuries among workers in manufacturing industries in Asia. ${ }^{3}$ In Malaysia, $21.9 \%$ of employees were reported to suffer from hearing impairment. Almost $90 \%$ of the reported occupational diseases in Sabah, Malaysian Borneo are due to hearing loss. ${ }^{4}$ The main sector that contributes to this magnitude of problem is the manufacturing industry as is evident by the increasing notification rate of NIHL. The palm oil industry was the commonest manufacturing industry in the east coast of Sabah. 
Continuous exposure to the noise source from the boiler machine in palm oil mills may lead to the progression of NIHL among its workers. Hence, this study aims to identify the prevalence and associated factors of hearing loss among noise-exposed workers in palm oil mills.

\section{Materials and Methods}

This cross-sectional study was conducted among 312 respondents from five palm oil mills on the east coast of Sabah, Malaysian Borneo from January to June 2019. The mills were randomly selected out of 67 available mills in the locality of interest based on the inclusion criteria of having a high level of noise workstation exposure of 85 $\mathrm{dB}(\mathrm{A})$ or above, over an 8 -hour time weighted average (TWA), as reported by the Roundtable Sustainable Palm Oil (RSPO) certified companies that are responsible for monitoring these palm oil mills. The number of mills selected was also subjected to the respective companies' approval as well as the time and budget limitation in this research. All workers from the chosen palm oil mills were included purposively in the study. The minimum sample size required was 212 based on the $83 \%$ prevalence of NIHL reported in the Malaysian study by Maisarah et al in 1993, with $95 \%$ confidence level and 40\% non-response rate. ${ }^{5}$ Those who have ear infections, had been treated for tuberculosis or undergone treatment with ototoxic drugs were excluded.

The tools used in this study include a pure tone audiometric test (PTA), validated questionnaires and a sound level meter. The PTA machine (Amplivox 240) had been calibrated according to the standard (ISO 389-3 1994/ American National Standard Specification for Audiometers S3.6-1969) by an authorised person. ${ }^{6}$ Hearing loss was diagnosed when there is a permanent threshold shift of $25 \mathrm{~dB}$ or more in the frequency range of $500 \mathrm{~Hz}, 1 \mathrm{kHz}, 2 \mathrm{kHz}$ and $3 \mathrm{kHz}$ compared to the baseline audiometric reference level as stated in the Malaysian Factories and Machinery Act $1967 .{ }^{6}$ Consented participants were interviewed for information such as their sociodemographic data (gender, age, marital status, type of job and hobbies such as listening to loud music, karaoke singing, shooting and diving), occupation (duration of employment, works with noisy machinery, overtime hours per week, noise exposure level $\mathrm{dB}(\mathrm{A})$ ), and comorbidities (smoking and diabetes). The questionnaire was adopted from a study done among fertilizer factory workers in Sarawak developed by Saffree Jeffree et al. ${ }^{7}$ The validation of the content in the questionnaires was done by cross-reference and verification from the experts. A sound level meter (SLM) was used for acoustic measurement (Model - 2700: Type 2 ANSI S1.4-1983, IEC 651-1979). It is a handheld device with an attached microphone that consists of a diaphragm which will respond to the changes in air pressure brought by the variations in sounds. The recorded unit of measurement was in decibels (dB). Procedures of acoustic measurement was according to the guidelines by the Malaysian Department of Environment (DOE). ${ }^{8}$

The statistical analysis was performed using SPSS software version 23.0 (SPSS, Chicago, IL, USA). Descriptive analysis was conducted using frequencies and percentages for categorical variables, whereas mean and standard deviation for numerical variables. Pearson chi-square test and independent $t$-test were used to determine the association between independent and dependent variables for categorical and numerical variables, respectively. Fisher's exact test was used for variables with a cell size less than five. Statistically significant data were determined by a p-value of less than 0.05 with a prevalence ratio (PR) and $95 \%$ confidence interval.

\section{Results}

$234(75 \%)$ of the respondents were diagnosed with hearing loss in this study. Most of them were male $(96.2 \%, \mathrm{n}=$ 300 ) with a mean age of 44.4 (SD 9.8) as shown in Table $1.84 .6 \%(\mathrm{n}=264)$ of the respondents were married and $95.2 \%$ serve as blue-collar workers $(n=297)$. The mean duration of employment and mean overtime hours per week were 16.2 (SD 9.7) years and 5.9 (SD 2.7) hours, respectively. $219(70.2 \%)$ of the respondents work directly with noisy machinery with a mean noise exposure of 96.1 (SD 4.8) dB(A).

Table 2 shows the results of univariate analysis between the variables under study. Older age $(\mathrm{p}=0.001$, mean difference: $9.904,95 \%$ CI: 6.785, 11.403), married $(p=0.001$, PR: $1.844,95 \%$ CI: 1.331, 2.555), blue-collar job ( $\mathrm{p}=0.003$, PR: $1.919,95 \%$ CI: 1.029, 3.578), smoking $(\mathrm{p}=0.001$, PR: $1.459,95 \%$ CI: 1.270, 1.676), works with noisy machinery $(\mathrm{p}=0.005$, PR: $1.232,95 \% \mathrm{CI}: 1.044$, 2.453), lower level of noise exposed $(\mathrm{p}=0.015$, mean difference: $1.580,95 \%$ CI: 0.292, 2.682), longer duration of employment $(\mathrm{p}=0.001$, mean difference: $8.188,95 \%$ CI: 5.992, 10.385), and longer overtime hours per week ( $\mathrm{p}$ $=0.001$, mean difference: $1.987,95 \%$ CI: $1.331,2.644$ ) were the significant factors for hearing loss. Recreational factors such as listening to loud music, karaoke singing, 
Table I Descriptive Analysis Among Noise-Exposed Workers in Palm Oil Mills $(\mathrm{N}=312)$

\begin{tabular}{|l|c|c|}
\hline Variables & $\begin{array}{c}\text { Frequency } \\
\text { (\%) }\end{array}$ & $\begin{array}{c}\text { Mean } \\
\text { (SD) }\end{array}$ \\
\hline $\begin{array}{c}\text { Gender: } \\
\text { Male } \\
\text { Female }\end{array}$ & $\begin{array}{c}300(96.2) \\
12(3.8)\end{array}$ & \\
\hline Age: & & $44.4(9.8)$ \\
\hline $\begin{array}{l}\text { Marital Status: } \\
\text { Married } \\
\text { Unmarried }\end{array}$ & $\begin{array}{c}264(84.6) \\
48(15.4)\end{array}$ \\
\hline $\begin{array}{l}\text { Type of Job: } \\
\text { Blue Collar }\end{array}$ & $297(95.2)$ & \\
White Collar & $15(4.8)$ & \\
\hline $\begin{array}{l}\text { Works with Noisy Machinery: } \\
\text { Yes }\end{array}$ & $219(70.2)$ & \\
\hline No & $93(29.8)$ & \\
\hline Noise Exposure dB(A): & & $96.1(4.8)$ \\
\hline Duration of Employment (year): & & $16.2(9.7)$ \\
\hline Overtime Hours/ week: & & \\
\hline
\end{tabular}

Abbreviations: $S D$, standard deviation; $\mathrm{dB}(\mathrm{A})$, A-weighted decibel.

shooting, diving, and medical conditions such as diabetes mellitus were not statistically significant.

\section{Discussions}

The prevalence of hearing loss among noise-exposed palm oil mill workers in Sabah was $75 \%$ with the mean noise exposure of 96.1 (SD 4.8) dB(A). The finding of high NIHL prevalence in palm oil industries is in line with other studies done in developing countries. ${ }^{9,10}$ Developed countries have lower prevalence of NIHL amongst their population due to its strengthened regulations, better control measures and increased awareness or knowledge. Despite the existing regulations, smoking and duration of employment were still the significant factors in this study population. Further studies on the compliance to existing control measures need to be considered. The implementation of hearing conservation programs among the palm oil mills involved is also questionable. Nonetheless, the reduction of noise at the source through engineering control is still the best method.

This study found that older age is a significant factor for hearing loss. A study done in the neighbouring state, Sarawak, also reported similar finding. ${ }^{7}$ The changes in the inner ear that occur as people grow older due to physiological reasons may exacerbated the progression of NIHL especially among noise-exposed workers. $^{11}$ However, there are many factors contributing to the impact of aging on the auditory system apart from the environmental factor, such as genetics and comorbidities. ${ }^{12}$ Another longitudinal study of pure-tone thresholds in older persons revealed that there was a decline of $0.7 \mathrm{~dB}$ per year at $0.25 \mathrm{kHz}$, increasing to $1.2 \mathrm{~dB}$ per year at 8 $\mathrm{kHz}$, and $1.23 \mathrm{~dB}$ per year at $12 \mathrm{kHz} .^{13}$

Marital status was found to have a significant association with hearing loss in this study especially among the married workers. This is not implying that having a stable relationship was the sole factors for having the condition. In this study, the mean age was 44.4 (SD 9.8) years. Normally at the age of 40 years old, people are already married. Age factors could be the confounding factor for marital status being significant in this study. ${ }^{14}$ Meanwhile, a study done in the USA found that adults with the lowest quality of hearing may depend more heavily upon the social support resources through living situations that include having a partner. ${ }^{15}$

The type of work carried out, especially a blue-collar job, was significantly associated with hearing loss. This finding is in line with the study conducted in Tanzania whereby the blue-collar workers are more exposed and directly work with the noisy machinery compared to the white-collar workers who are mostly supervisors. ${ }^{16}$

Few studies found out the significant relationship between hearing loss and smoking as revealed in this study. ${ }^{17-19}$ A study done in Korea concluded that being a current smoker was significantly associated with hearing loss at all frequencies among workers exposed to occupational noise, and being a heavier smoker influenced lowfrequency hearing loss more greatly. ${ }^{17}$ It has been well studied that the effect of nicotine causes vasoconstriction in the blood vessels. These vasoconstrictions can cause a reduced blood supply to the hair cells within the cochlear, which in turn would cause irreversible damage to the hair cells, thus increasing the effects of NIHL amongst the smoking population of workers. A proper follow up needs to be done among workers who smoke and are exposed to noise levels exceeding $85 \mathrm{~dB}(\mathrm{~A})$ as suggested by Pouryaghoub et al, 2007. ${ }^{20}$ Health education on the dangers of smoking and providing Quit Smoking clinics will benefit these workers.

A highly significant association was also demonstrated between hearing loss and longer duration of employment as supported in multiple studies. ${ }^{9,21,22}$ This is also implied 
Table 2 Univariate Analysis of Hearing Loss Among Noise-Exposed Workers in Palm Oil Mills

\begin{tabular}{|c|c|c|c|c|c|c|c|}
\hline \multirow{2}{*}{$\begin{array}{l}\text { Variables } \\
\text { Gender: }\end{array}$} & \multirow{2}{*}{$\begin{array}{c}\text { NIHL }(n=234) \\
(\text { No. } / \%)\end{array}$} & \multirow{2}{*}{$\begin{array}{c}\text { Non-NIHL }(n=80) \\
(\text { No. } / \%)\end{array}$} & \multirow{2}{*}{$\begin{array}{c}\text { Chi Square or } \\
\text { t-test }\end{array}$} & \multirow{2}{*}{$p$ value } & \multirow[t]{2}{*}{ PR } & \multicolumn{2}{|c|}{$95 \% \mathrm{Cl}$} \\
\hline & & & & & & & \\
\hline Male & $228(76.0)$ & $72(24.0)$ & $0^{\mathrm{a}}$ & 0.080 & 1.520 & 0.860 & 2.686 \\
\hline Female & $6(50.0)$ & $6(50.0)$ & & & & & \\
\hline Age: & $46.6(8.8)^{b}$ & $37.5(9.6)^{b}$ & $9.904^{c}$ & 0.001 & - & 6.785 & 11.403 \\
\hline \multicolumn{8}{|l|}{ Marital Status: } \\
\hline Married & $213(80.7)$ & $51(19.3)$ & 29.545 & 0.001 & 1.844 & 1.331 & 2.555 \\
\hline Unmarried & $21(43.8)$ & $27(56.3)$ & & & & & \\
\hline \multicolumn{8}{|l|}{ Type of Job: } \\
\hline Blue Collar & $228(76.8)$ & $69(23.2)$ & $0^{a}$ & 0.003 & 1.919 & 1.029 & 3.578 \\
\hline White Collar & $6(40.0)$ & $9(60.0)$ & & & & & \\
\hline \multicolumn{8}{|l|}{ Smoking: } \\
\hline Yes & |4| (88.7) & $18(11.3)$ & 32.358 & 0.001 & 1.459 & 1.270 & 1.676 \\
\hline No & $93(60.8)$ & $60(39.2)$ & & & & & \\
\hline \multicolumn{8}{|l|}{ Diabetic: } \\
\hline Yes & $33(84.6)$ & $6(15.4)$ & 2.198 & 0.138 & 1.149 & 0.988 & 1.337 \\
\hline No & 201 (73.6) & $72(26.4)$ & & & & & \\
\hline \multirow{2}{*}{\multicolumn{8}{|c|}{$\begin{array}{l}\text { Works with Noisy } \\
\text { Machinery: }\end{array}$}} \\
\hline & & & & & & & \\
\hline Yes & 174 (79.5) & $45(20.5)$ & 7.767 & 0.005 & 1.232 & 1.044 & 1.453 \\
\hline No & $60(64.5)$ & $33(35.5)$ & & & & & \\
\hline Noise Exposure dB(A): & $95.7(4.9)^{b}$ & $97.2(4.5)^{b}$ & $1.580^{c}$ & 0.015 & - & 0.292 & 2.682 \\
\hline Duration of Employment: & $18.2(9.4)^{b}$ & $10.0(8.2)^{b}$ & $8.188^{c}$ & 0.001 & - & 5.992 & 10.385 \\
\hline Overtime Hours/ week: & $6.4(2.5)^{b}$ & $4.4(2.7)^{b}$ & $1.987^{c}$ & 0.001 & - & 1.331 & 2.644 \\
\hline \multicolumn{8}{|l|}{ Listens to Loud Music: } \\
\hline Yes & $42(68.9)$ & $19(31.1)$ & 1.528 & 0.216 & 0.900 & 0.750 & 1.080 \\
\hline No & $192(76.5)$ & $59(23.5)$ & & & & & \\
\hline \multicolumn{8}{|l|}{ Karaoke singing: } \\
\hline Yes & $48(72.7)$ & $18(27.3)$ & 0.231 & 0.631 & 0.962 & 0.816 & 1.133 \\
\hline No & $186(75.6)$ & $60(24.4)$ & & & & & \\
\hline \multicolumn{8}{|l|}{ Shooting: } \\
\hline Yes & $9(75.0)$ & $3(25.0)$ & $0^{\mathrm{a}}$ & 1.000 & 1.000 & 0.717 & 1.395 \\
\hline No & $225(75.0)$ & $75(25.0)$ & & & & & \\
\hline \multicolumn{8}{|l|}{ Diving: } \\
\hline Yes & $21(77.8)$ & $6(22.2)$ & 0.122 & 0.727 & 1.041 & $0.84 I$ & 1.287 \\
\hline No & $213(74.7)$ & $72(25.3)$ & & & & & \\
\hline
\end{tabular}

Notes: ${ }^{a}$ Fisher's exact test, ${ }^{b}$ mean (SD), ${ }^{c}$ mean difference.

Abbreviations: NIHL, noise-induced hearing loss; PR, prevalence ratio; $\mathrm{Cl}$, confidence interval; SD, standard deviation.

for those workers who had done more overtime hours and directly work with noisy machinery. This study also found that there is a significant difference in the mean noise exposure level whereby lower levels of noise exposure are associated with NIHL. This might be due to the difference in the duration of exposure, as such the noise exposure was longer in the group of workers exposed to lower levels of noise. Moreover, the total mean noise exposure for both groups was more than $85 \mathrm{~dB}(\mathrm{~A})$. The increased incidence of NIHL among workers who have 
served for a longer duration is likely due to the increased cumulative exposure to noise. As with any hazard, repeated long term exposure would result in increased incidence of the disease. In this study, the mean duration of employment was 16.2 (SD 9.7) years for all workers whereas it was 18.2 (SD 9.4) years among the NIHL. Most of the hearing loss occurs during the first 10 years of noise exposure. ${ }^{23}$ For example, the median expected noiseinduced permanent threshold shift (NIPTS) of 3-6 kHz at $85 \mathrm{~dB}(\mathrm{~A})$ noise exposure level normalized to a nominal 8-hour working day for 10 years is $4 \mathrm{~dB}(2-5 \mathrm{~dB}$ for the 10-90 percentile), whereas it was $5 \mathrm{~dB}$ (3-7 dB for 10 90 percentile) after 40 years. However, there was no information on the previous noise exposure from other jobs among the participants which might affect the study findings.

\section{Conclusion}

This study found that there was a high prevalence of hearing loss among palm oil mill workers. The study demonstrates the practical importance of a series of annual audiometry testing, implementing medical removal programs for the early stage of NIHL and job rotation for highly exposed workstation workers. The introduction of a smoking cessation program by employers may reduce the prevalence of workers having hearing loss. The best control, still, is the reduction of noise at the source by engineering methods. The immediate future study recommendation is to conduct a more detailed study with samples taken from a larger company. This would further strengthen the findings and possibly find more significant associative factors of hearing loss.

\section{Data Sharing Statement}

Data are available upon request to the authors.

\section{Ethical Consideration}

This study complies with the Declaration of Helsinki and has received ethical approval from the Medical Research Ethics Committee of Universiti Malaysia Sabah [JKEtika 2/19 (4)]. The respondent administrator has given permission to conduct the study. Written informed consents were obtained from the study participants prior to study commencement.

\section{Acknowledgment}

We would like to express our gratitude to the palm oil mill's management teams involved for their continuous support and cooperation.

\section{Funding}

There is no funding to report.

\section{Disclosure}

The authors report no conflicts of interest in this work.

\section{References}

1. National Institute on Deafness and Other Communication Disorders NIDCD. Noise induced hearing loss; 2014. Available from: www. nidcd.nih.gov/staticresources/health/hearing/NIDCD-Noise-

InducedHearing-Loss.pdf. Accessed June 08, 2020.

2. World Health Organization. Guidelines for community noise. In: Berglund B, Lindvall T, Schwela DH, editors. Geneva: WHO; 1999.

3. Chen Y, Zhang M, Qiu W, et al. Prevalence and determinants of noise-induced hearing loss among workers in the automotive industry in China: a pilot study. J Occup Health. 2019;61(5):387-397. doi:10.1002/1348-9585.12066

4. Malaysia Department of Occupational Safety and Health. Malaysia statistics report 2016.

5. Maisarah SZ, Said H. The noise exposed factory workers: the prevalence of sensori-neural hearing loss and their use of personal hearing protection devices. Med J Malaysia. 1993;48(3):280-285.

6. Malaysia Department of Occupational Safety and Health. Factories and Machinery Act 1967 (Act 139). Factories and Machinery (Noise Exposure) Regulations 2019.

7. Saffree Jeffree M, Ismail N, Awang Lukman K. Hearing impairment and contributing factors among fertilizer factory workers. $J$ Occup Health. 2016;58(5):434-443. doi:10.1539/joh.16-0043-OA

8. Malaysian Department of Environment. Guidelines for Environmental Noise Limits and Control. Third ed. 2019.

9. Bright O, Paul AO, Confidence CO. Auditory effects of noise and its prevalence among sawmill workers. Int J Med Med Sci. 2018;10 (2):27-30. doi:10.5897/ijmms2017.1344

10. Jamal A, Tanoli Q, Putus T, Savolainen H, Liesivuori J. Noise induced hearing loss and its determinants in workers of an automobile manufacturing unit in Karachi, Pakistan. Madridge J Otorhinolaryngol. 2016;1(1):1-11. doi:10.18689/mjol-1000101

11. Cruickshanks KJ, Tweed TS, Wiley TL, et al. The 5-year incidence and progression of hearing loss: the Epidemiology of Hearing Loss Study. Arch Otolaryngol Head Neck Surg. 2003;129(10):1041-1046. doi:10.1001/archotol.129.10.1041

12. Jayakody DMP, Friedland PL, Martins RN, Sohrabi HR. Impact of aging on the auditory system and related cognitive functions: a narrative review. Front Neurosci. 2018;12:125. doi:10.3389/ fnins. 2018.00125

13. Lee F-S, Matthews LJ, Dubno JR, Mills JH. Longitudinal study of pure-tone thresholds in older persons. Ear Hear. 2005;26:1-11. doi:10.1097/00003446-200502000-00001

14. Pyykko I, Pekkarinen J, Starck J. Sensory-neural hearing loss in forest workers. An analysis of risk factor. Int Arch Occup Environ Health. 1986;59:439-454.

15. Denney JT PhD, Boardman JD PhD, Zajacova A. Hearing impairment, household composition, marital status, and mortality among U.S. adults. J Gerontol B. 2021;76(1):201-208. doi:10.1093/geronb/ gbz157

16. John W, Sakwari G, Mamuya SH. Noise exposure and self-reported hearing impairment among gas-fired electric plant workers in Tanzania. Ann Glob Health. 2018;84(3):523-531.

17. Sung JH, Cs S, Cr L, et al. Relationship of cigarette smoking and hearing loss in workers exposed to occupational noise. Ann Occup Environ Med. 2013;25:8. doi:10.1186/2052-4374-25-8 
18. Mohammadi S, Mazhari MM, Mehrparvar AH, Attarchi MS. Cigarette smoking and occupational noise-induced hearing loss. Eur J Public Health. 2010;20(4):452-455. doi:10.1093/eurpub/ckp167

19. Bae SH, Kwak SH, Choi JY, Jung J. Synergistic effect of smoking on age-related hearing loss in patients with diabetes. Sci Rep. 2020;10 (1):18893. PMID: 33144636; PMCID: PMC7641162. doi:10.1038/ s41598-020-75880-2

20. Pouryaghoub G, Mehrdad R, Mohammadi S. Interaction of smoking and occupational noise exposure on hearing loss: a cross-sectional study. BMC Public Health. 2007;7(1):137. doi:10.1186/1471-2458-7-137

21. Feder K, Michaud D, McNamee J, Fitzpatrick E, Davies H, Leroux T. Prevalence of hazardous occupational noise exposure, hearing loss, and hearing protection usage among a representative sample of working Canadians. J Occup Environ Med. 2017;59(1):92-113. doi:10.1097/JOM.0000000000000920
22. Suadicani P, Hein HO, Gyntelberg F. Occupational noise exposure, social class, and risk of ischemic heart disease and all cause mortality - a 16-year follow-up in the Copenhagen Male Study. Scand J Work Environ Health. 2012;38(1):19-26. doi:10.5271/ sjweh. 3200

23. Durch JS, Joellenbeck LM, Humes LE, eds. Noise and Military Service: Implications for Hearing Loss and Tinnitus. Washington, DC: National Academies Press; 2005.
Risk Management and Healthcare Policy

\section{Publish your work in this journal}

Risk Management and Healthcare Policy is an international, peerreviewed, open access journal focusing on all aspects of public health, policy, and preventative measures to promote good health and improve morbidity and mortality in the population. The journal welcomes submitted papers covering original research, basic science, clinical \& epidemiological studies, reviews and evaluations,

\section{Dovepress}

guidelines, expert opinion and commentary, case reports and extended reports. The manuscript management system is completely online and includes a very quick and fair peer-review system, which is all easy to use. Visit http://www.dovepress.com/testimonials.php to read real quotes from published authors. 